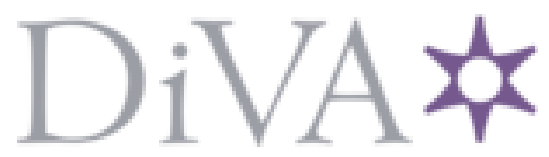

http://www.diva-portal.org

This is the published version of a paper published in Sport Science Review.

Citation for the original published paper (version of record):

Larsson, L., Meckbach, J. (2013)

To be or not to be invited: Youth Sport - Young people's influence in voluntary sport..

Sport Science Review, 22(3-4): 187-204

http://dx.doi.org/10.2478/ssr-2013-0009

Access to the published version may require subscription.

N.B. When citing this work, cite the original published paper.

Permanent link to this version:

http://urn.kb.se/resolve?urn=urn:nbn:se:gih:diva-2914 


\title{
To Be or Not to Be Invited Youth Sport: Young People's Influence in Voluntary Sport
}

\author{
Lena LARSSON ${ }^{1} \cdot$ Jane $\mathrm{MECKBACH}^{2}$
}

\begin{abstract}
Tnfluence and the opportunity to have one's voice heard are
fundamental rights valid for all people, including also children and youths. Despite this, research shows that young people's voices have received less attention and young people have no influence in many contexts in which they find themselves (Evans, 2007; Fundberg, 2009; Redelius, 2005). In Sweden, the emphasis on influence can be linked to the fact that the sport club activities of the Swedish state are seen as an important arena for the civic education of young people (The Swedish Sports Confederation, 2005, 2011). The aim of this study is to explore young coaches and their opportunities to influence in the Swedish sport clubs with focus on what the youths themselves say about influence and power. We use Bourdieus' theories on social fields to bring to light which youths are chosen to be leaders and their possibilities to influence. The results show that for young coaches to have influence, both their habitus and capital are required to 'match' the social context into which they are entering. One way of maintaining power is not to change the accepted way of working, which excludes the young coaches from challenging in the battle for positions.
\end{abstract}

Keywords: influence, Bourdieu, habitus, young coaches, sport

1 Linneaus University, Kalmar, Sweden

2 The Swedish School of Sport and Health Sciences, Stockholm, Sweden 


\section{Introduction}

Influence and the opportunity to have one's voice heard are fundamental rights valid for all people. Influence in the form of opportunities to have impact and hold power is a democratic right that includes also children and young people. Despite this, research shows that young people's voices have received less attention and young people have no influence in many of the contexts in which they find themselves (Evans, 2007, p. 693). One context that many youths in Sweden find themselves in is different sport associations, and sports are without exception the most popular leisure activity for Swedish children and youth (Nilsson, 1998; Larsson, 2005). In Sweden, traditionally the sports association is responsible for the organization of both the voluntary training and the competitions in sports for children and youth. The Swedish sport associations are built on democratic principles and fundamental values, which means that children and youth should be able to have impact and exert influence (The Swedish Government, 2008).

Members' opportunities for democratic influence have historically been seen as the basis for the Swedish sport associations and this is so also today (The Swedish Government, 2005, 2011). Both the national sports policy (The Swedish Government 1999) and the sport association policy document (The Swedish Sports Confederation, 2005a) state that all participants should have equal opportunity to make their voice heard and exert influence. In Sweden in 2004 a youth policy proposition (The Swedish Government 2004) was accepted that is still valid today. There are mainly two overriding objectives: "that youth shall have real access to welfare and that they shall have real access to power" (The Swedish Government, 2004, p. 25) meaning that for the youths to be able to participate, they should be given influence on the society issues that concern them. Youths' opportunities to influence are described by the sport associations as a matter of survival (The Swedish Sports Confederation, 2005a; Youth Council, 2011). Several initiatives have been carried out in order to increase youths' possibilities for participation and influence both on a central and a local level in sports; one group of efforts is directed mainly towards young people who have leader assignments (Redelius, 2005; Larsson \& Meckbach, 2010; Meckbach \& Larsson, 2011; 2012). The emphasis on this group can be linked partly to the belief that investment is a way to retain young leaders and partly to the belief that the opportunities to influence are greater for leaders than for players. The responsibility for the young leaders to obtain real influence rests on the individual clubs as well as on the activity in general (The Swedish Sports Confederation, 2005a, 2011). 
Though official reports and policy documents state that sport associations should give youth power and influence, research about youths' influence in the sport associations has been scarce. A lot of attention has been given to youth participating in sport associations (Nilson, 1998; Butcher et al., 2002; Sarrazin et al., 2002; Franzén \& Peterson, 2004) and youths' rights and opportunities to participate (MacPhail et al., 2003; Trondman, 2011; Svender et al., 2012) while questions regarding youths' opportunities to make their voice heard, youths' opportunities to impact and youths' opportunities to get a place on the sport's governing board, have been ignored. This is also valid in an international context.

The aim of this study is to explore young coaches' possibilities and experiences and ideas of influence in the Swedish sport associations with focus on the youths' own voices about being chosen to be coach, getting influence and holding power. The specific questions are as follows: (i) which young coaches are believed to be capable of having an influence? $i$ ) what means of influence do the young coaches experience that they have?

\section{Youths' influence}

International research shows that those youths who are given the opportunity to make an impact, experience their participation as meaningful. Evans (2007) found from his study with teenagers that young people "feel a stronger self-described sense of community in contexts in which they experienced voice and resonance, some power and influence, and adequate adult support and challenge" (p. 699). According to Evans, teenagers want to participate and exert influence, but he states that most young people "are excluded from many of the decision-making processes that affect their lives" (2007, p. 705). Evans also shows that if teenagers get adequate help from adults and are given the opportunity to influence, there is a gain for both the youths and the society by contributing to their empowerment. According to Evans, not just any teenagers can influence, but rather help from significant adults, the right socio-economic background and supportive structures in the school and society are also required. Nelson and Prilleltensky (2005) argue that it is the relationship between the individual's ability and position together with the specific context structures that determine whether the feeling of having influence also means the real power to influence. Einarsson (2008) also indicates the importance of structures that are supportive. He shows that in sports it is easier to gain influence in smaller clubs and that the form of the meetings has importance for the degree of influence youths have. Smyth (2006) in turn shows that primarily relational changes, and not structural, are needed in order for teenagers to gain influence. According to Smyth, relational changes involve things like allowing their voices to be heard, 
involving them in real decisions, including and respecting them, and giving them feedback that enables them to grow.

The overall picture research gives is that participation is not automatically an opportunity for teenagers to influence, but instead measures are required on both a relational and a structural level in order for youths to be able to exert influence.

\section{Influence in sport associations}

In Sweden there are over 20,000 local sport clubs. The foundation of the Swedish sport association is lack of profit and member democracy. On the local level, the members' right to influence and right to vote at the annual meeting are safeguarded in the association's bylaws. Decisions about the club's activities are taken partly at the annual meeting and partly by the association's governing board. The association in turn appoints representatives for the members' actions at the regional level and the national level (Pallin, 2004; The Swedish government 2008).

More than three million of Sweden's population are members of one or more sport clubs, and approximately 600,000 are active as leaders. The majority of the leaders work as volunteers. Earlier studies show that many teenagers are involved as leaders and that many more, both boys and girls, could be recruited since many reveal that if they were only asked, they would gladly become leaders (Trondman, 2005; Redelius, 2007; The Swedish Sports Confederation, 2005b). What has proven to be significant for involving youths as leaders are things like the youths being able to participate and decide and feel involved (Redelius et al., 2004; Trondman, 2011). Previous research (Norberg, 2011; Trondman,2005; The Swedish Sports Confederation 2005b) shows that it is difficult to increase the influence of young people, and Swedish sport clubs have not been particularly successful in this task. According to Trondman (2005) only a small proportion (37\%) of youths between 13-20 years old experiences that they have influence in their own association. At the same time, Trondman points out that the issue of influence is complex, and that it is not certain that youths share the same ideas about influence as the state and the sport associations, and that $85 \%$ are satisfied and do not want to have greater influence.

The matter also involves which opportunities for influence the sport clubs offer youths. The annual association meeting is regarded as an important arena for exerting influence, as is being a club committee member; but in terms of responsibilities as a member of the board or on a task force, then only a few youths have had such a duty, and it has been difficult attracting young coaches 
to these arenas (Redelius et al., 2004; Trondman, 2005; The Swedish Sports Confederation, 2005b). Regarding being on a committee, Fundberg (2009) shows that it is important to have the right contacts, since most people are recruited via a network that is characterized by like-minded people rewarding each other. Not just anyone is allowed to enter the field and attain a position that generates influence; it is also necessary for one to have the right symbolic capital. The conclusion drawn by Redelius (2005) is that young people often lack valid capital, i.e. they still do not have the necessary experiences and assets.

\section{Theoretical Framework}

Influence, as mentioned above, is a concept that can have multiple meanings. The present study focuses on the young leaders' opportunities to influence and participate in decisions in the sport clubs. To be able to participate in decisions and have influence are intimately connected with the power to impact. We use Bourdieu's theories on social fields in order to illuminate which youths are chosen to be leaders and their opportunities to influence. A social field in Bourdieu's sense is characterized by a distinct group of people and institutions striving for something in common for all of them (Bourdieu, 1993). Based on Bourdieu's theories, certain social contexts can be regarded as social fields. One such is the sports field, which is characterized by having its own logic and defining its own rules, rules that everyone within the field must abide by and that often are obvious and taken for granted (Bourdieu, 1988, 1997; Munk, 1999; Munk \& Lind, 2004).

By the concept field Bourdieu means, simply expressed, that a certain distribution structure of power or capital applies (Bourdieu, 1995). Bourdieu equates power with different types of assets that give the holder a position that renders influence (Bourdieu, 1977, 1994). Admission to a social setting or in a social field, does not automatically give the power to influence. What counts is to have the assets that serve as the capital in the sport context. Having Swedish background, a good education and male gender have been previously shown to function as the capital necessary to be asked and selected to be a coach in the association. The majority of the coaches are men, and the majority of the young people asked if they want to be coaches are men (Redelius, 2002; Trondman, 2005; Redelius, 2007; The Swedish Sports Confederation, 2011). Assets shown to be important for getting the opportunity to influence, besides being a man, are to have a background in the sport and to be a part of the network (Fundberg, 2009).

Assets in Bourdieu's sense deal also with embodied experience, habitus. This is not just any habitus, but one must have the "right" habitus based on what is required in that specific setting (Bourdieu, 1990, 2000). Young coaches must have a habitus allowing them to act in such a way that gives them legitimacy 
in the sport context they enter, if they are going to have some possibility to influence. Seen in earlier studies, the right habitus for a coach involves having experience in the sport club; both adults and youths that are recruited to be coaches come from their own ranks (Nilsson, 1998; Redelius, 2005; Trondman, 2005; Larsson \& Meckbach, 2010: Meckbach \& Larsson, 2011; 2012).

In other words, the possibility to influence has to do with the relationship of the young coaches' habitus, capital and the sport context they find themselves in. Bourdieu's theories make it possible to investigate both the habitus and the capital required for young coaches to be able to participate in the struggle for positions in the sport association. The theories also allow us to penetrate and illustrate the value structures and patterns of behavior in a social practice such as the sport association. Thus, the starting point is that the sport association is a social field in which the youths' incorporated experiences, together with the objective structures, determine who is allowed to enter and influence the field.

\section{Research Design}

The data in this study consists of focus group interviews with young coaches, and the interviews are semi-structured (Marshall \& Rossman, 2011). Ten focus group interviews were conducted with thirty-seven participants who participated in leadership training for young coaches in sport clubs, of which twenty were women and seventeen were men. The selection of respondents included a geographical spread, a variety of sports, and both male and female participants. The number of participants in the focus groups varied between three and five.

Focus group interviews were chosen with the aim of acquiring a deeper understanding of the encounter between the young coaches' experiences and ideas, and the social conditions that regulate the sport associations. The interviews were semi-structured and based on four areas: personal narratives, leadership experience, leadership position, and youth influence. The interviews were recorded and transcribed afterwards.

By means of qualitative text analysis (Denzin \& Lincoln, 1998) the statements were examined based on the aims of the study and subsequently interpreted with the theoretical framework as the starting point.

\section{Findings}

The findings of this study have been organized into two sections; the first section is about which youths are selected to be coaches, in other words, which youths are believed to be capable of exerting an influence. 
The second section is about the young coaches' possibilities to exert influence and how the youths themselves experience being able to influence.

\section{Being selected}

The "right" experience. As described above, youths' opportunities to influence in sports are believed to be greater for those who are coaches. The question is who will be the coaches. The results of this study show that it is not just any youths that are asked to be coaches or just anybody who says "yes." Having been or being active athletes in a sport club is a prerequisite for youths both to be asked and to be able to accept the offer. The youths say the clubs select who will be asked, and the associations ask those youths who have been and are active in the club.

I am rather new to the coach role. I was active up to last year when I stopped swimming myself and quit and became a trainer instead...at our office which is a little mixed at the club level. She found out about this training for future coaches and thought that I and another new coach should probably go to it, that it could be something for us because we are interested and so on (interview 3).

For many youths, sports have been an interest shared by the whole family, something that they have done together throughout their upbringing. None of the young coaches in the present study has a more general sports interest or is someone with leadership experience from an area outside of sports, which may be the case with older trainers (see Redelius 2002). The selected young people feel comfortable in sport clubs. They describe athletic training as integrating them in an environment that "functions as an extra upbringing... a lot of time is spent at the training and there is always a coach... a little like an extra parent" (interview 9).

Beyond sports experience, other experience is also required in order to be considered, like school is emphasized. The youths' own accounts reveal the most common prerequisites: either they took a preparation course in high school or they study at the university, and they have Swedish background. In addition to specific experiences and assets, their comments reveal that most often "a helping hand" is also required, someone who approaches and asks. If "the helping hand" has a position or assets valued in the sport, it is an extra bonus.

What can I say, it was my dad. He is on the board and he works there, so he told me that I could go here (interview 1).

Being "a leader type". A good candidate shows ability, is "a leader type" and has good self-confidence. When the youths describe themselves, they often 
speak of how they assumed the leadership role when they were active or when they were in school.

For me I have almost always taken up the leader role; it does not matter what I have done -- if it was in school, group work. I always automatically do it; I want to make things happen. But then it was only that I am on the youth council as chairperson and so became nominated so that I got in the district youth council because they wanted to get me in there when I took the youth leadership course (interview 6).

The youths explain accepting their leader assignments because they see the leadership role as an investment in their future that generates assets, assets that the youths believe can be converted in circumstances even outside of sports. They see the leadership task as a step in their future career, a career that started in sports. Many began as leaders for children, but they quickly got other groups or looked into getting other tasks, starting with things like the youth council in their own organization. These assignments later led to the district or the national level.

I was asked by the SDF (local sport association) or they suggested it was an advantage to go to this course in case I wanted to continue to be the team's trainer for the '96-girls. Because I... well, so they said and then I wanted to attend this course (interview 2).

The results show that in order to be considered to be a young coach and thus get the possibility to have one's voice heard, requires that the club acts and asks, that the individual perceives him or herself as "a leader type" and the role is believed to be an investment that can yield benefits even outside sports.

\section{Opportunities for influence}

The rules of the game. The youths feel they have little opportunity to influence. If they are to have influence, they must acquire it; it is nothing they are offered. Even if they would like to have influence, there are structural barriers hindering it. Learning the rules of the game and taking structural measures are both necessary. Most often they have experience matching the field, but they lack both resources and enough insight about the rules for legitimacy and ultimately about their position to influence. According to the young coaches, to be able to influence requires first and foremost that they learn what is valid for their own club.

I had perhaps an idea ... And then when the trainer presents the whole club's approach, then that got me thinking also along new lines. So one probably does not have only one path to follow; one has one's own 
from the beginning and then one mixes it with the whole vision of the club. But one cannot mix it too much, because the intention is for the whole club to have the same (interview 9).

Many of the young coaches, for example, have never been to an annual meeting and do not know who is on the board or what happens there. Those that have been to the annual meeting or something similar give the impression that they did not feel comfortable there in that environment. They neither could master nor understand the meeting procedure. The formal way of working on the board and at the annual meeting was seen by the young coaches as a hindrance which worked against their possibilities to influence, and if one wants "to have new energy on the boards, then one must review the way it works" say the youths (Interview 4). The way the board works functions as a barrier and maintains something that has always been, a working style that excludes young people.

It is also too bad that those on the board that I am on say that on this board we work like this, and if you as a young coach fit in like this, then it is great because we do not want to change anything. [...] One works the way they work, and if you can fit in, it is fun for you (interview 1).

A springboard for learning the rules of the game, according to the young coaches, is the work on the club's youth council. Not all clubs have a youth council. If there is one, it provides the chance to learn the meeting technique and the meeting procedure that is current, to voice opinions and practice expressing oneself both in speech and in writing.

Yes, and so it is preparing for the big board also. If you have been in the youth council, you know roughly about what it involves (interview 5).

In the youth council, the young leaders can incorporate "the right language" and learn the predominant technique in order gradually to dare and be able to take a seat.

\section{Structural measures}

According to the young coaches, more formal structural changes, like in the coach training, are also required. The training is important to the young coaches in order both to create interest for this type of issue and to provide the tools for obtaining a position with the right to speak.

...but when I got to attend this course later, it really aroused my interest significantly more about how one can actually influence; one can 
actually be involved a little more. So I think this course has taught me a lot from that perspective and it is perhaps something one can put more effort in... (interview 7).

Several of the young coaches in the study participate in the "Sports leadership programme" that has an emphasis on strategic and administrative leadership.

I began as a youth supervisor in my club and then became chairperson of my association. I have worked with 15 and 16-year-olds on the district level and served on the youth committee there also. And then in the last years I have been on a task force for children and youths' issues in the Swedish orienteering league also, and now I am participating in this course (Sports leadership programme, author's note) (interview 7).

Another structural factor of importance is the distance between those who sit on the board and the youths that can or want to be coaches. The larger associations often have an organized system for taking care of the new leaders, while in the smaller clubs there is closer contact between the board and the young coaches. The smaller clubs are also more dependent on everyone staying in the club. The short distance in the smaller club means that the youths are incorporated into the association duties in a natural way:

... more or less to help out and then in different ways one automatically gets to be a leader or gets to be on the board. So I think it becomes a natural transition for players in the club (interview 6).

In the clubs where the youths feel they have the possibility to influence, there is often something or someone acting as a link or bridge between them and the board. There can be support persons like a parent or another person whom the youths know or there is a set strategy, for example, the youth council, where young leaders can get increased responsibility and influence.

\section{Acquiring a position}

The environment in the club, as well as in the district and on the national level, appears in the interviews as very hierarchical. According to the youths, to be able to run for a position requires having a duty in the club board, association or something similar. Decisions are taken on the board, and it is at the board meetings where the important discussions take place, and often the young coaches are not invited to those meetings. The step from being a coach for children and youths to going to a meeting or having a board position appears 
almost insurmountable. The youths do not have the right knowledge and insight: "I can see now when I have studied a little economy that it would have been good if the treasurer had gone through what everything meant" (interview 4) and they are not full members on the board but instead "are placed at a children's table and do not get to participate" (interview 6).

Some have been offered a place on the board so that there is a youth representative, but too often the young coaches experience that the club is not interested in sharing in their experiences and ideas.

I got asked to be on the board just for being a teenager and all that, but I felt that I did not really have the time. We are of course welcome to the annual meeting and such, and I was at the last annual meeting so that ... then I got a special invitation because I would get an award (interview 2).

According to the youths, one attends the board meetings more for the excuse that there must be a youth representative on the board and less for the participation in discussions and decisions They are offered a position that in reality is being a representative for young people and a tool for the club to show on paper that they are living up to the policy document intentions.

According to the youths, being able to position oneself requires help in the form of things like affirmative action and bolstering by someone who already holds a position so that "one learns the power play" (interview 4). Not just anyone can succeed in this. One must have the right assets, be able to play the game and have the courage to challenge.

My experience is that one can settle in. One has to make it clear that it is their loss if they do not choose youths, and one never knows if he does not try. But then one grows also as a person, also the hard way. Not everyone can do it so we have a hard time with youths on our boards (interview 6).

The right assets are about whom one leads, what type of leader one is and which position one holds. If one wants to have more influence and have a role at the district or the national level, the young people say one should not lead children's sports. It is considered more valuable to train elite competitors and older youths than to train children and beginners.

But I know that they reward the trainers of elite groups and competition groups. I have been a trainer for six years but only... because I think it is fun to have beginners, those who have jumped one or two 
years. I do not think it is as fun with the tournament jumpers, but it can be those trainers who have only trained one year that get to attend courses so that they are competition trainers (interview 3).

Even more effective for acquiring a position in the sport association is to hold duties as an organization leader at the district or the national level. But according to the young coaches, there are few clubs that invest in their young coaches as organization leaders; many clubs lack candidate selection and have not even thought that one can ask youths.

Our club is probably rather typical. I have never been to an annual meeting in all my years. We are good at getting trainers for children; but regarding the board, we are a catastrophe (interview 6).

Young coaches feel that those who decide neither have confidence in the youths' abilities nor realize they are quite interested. The mistrust occurs in both directions, like when the young coaches express distrust towards the board and towards those who hold power positions and say that "more or less they count on the board remaining as is" (interview 10). The board members are described in terms of "board men in suits" (interview 3) and "men who have sat there for thirty years and done the same thing and can decide everything in their heads" (interview 7). Age is both an asset and an effective barrier that closes out the young leaders; "all the board members are twice as old as I am. I think all of them except one are probably three times as old. One does not feel any direct community there" (interview 8).

\section{Discussion and conclusions}

Similar to other studies (Redelius, 2007; Meckbach \& Larsson, 2011) the present results also show that not just anybody is considered for a leader assignment and is given access to the sports field, but it is required that the youths have the habitus and the capital matching those requested. Having a background as an active sportsperson emerges as a given prerequisite. The young coaches' sport experience is thought to function as a form of embodied capital, allowing them to become chosen and to be prepared to assume leadership duties. The prospective leaders are expected to have a taste for sports and that they can or have already incorporated that which Bourdieu (1994) calls the field logic, "the rules of the game." At the same time the results show that even if the young coaches have the habitus and the capital required in order to be considered as coaches, it does not mean that the capital gives returns in the form of a position in the field and thereby the possibility to influence, because the young coaches are also required to be aware of the collective attitudes, norms and 
principles valid for the sport and the individual association. In Bourdieu's terms, it is about figuring out the rules of the rulers, which are taken for granted and not questioned, as "the rule of order" (Bourdieu, 1992).

In the eyes of the youths, those who hold leading positions in the sport association could be described using Bourdieu's theories (1977) as the orthodox, those that in order to hold onto their power are afraid to let in the young coaches, who in the long run may threaten their position. Bourdieu believes that power breeds power (Bourdieu, 2004). One way of maintaining power, which appears successful for those who have a position within a field, is not to change the accepted way of working and, with that, exclude the young coaches from challenging in the battle for positions. Holding a committee post becomes a sort of self-generating system, which means that symbolic capital is assigned to those who are on the committee and already have capital. It is about preserving the order that is and always has been, and acting to counter those who might question it. It is up to the new to adapt to the existing rules.

In order to win a position and thereby get the opportunity to influence, certain strategies appear more successful than others. A strategy in this case should be seen as an unconscious relationship between the habitus and a field (Bourdieu, 1992). One way is to attend coach training that gives access to the field and that can function as a springboard for reaching higher positions. According to Bourdieu and Passeron (2008) training is a way to inculcate a legitimate culture. This is something that sport associations are thought to have adopted; the coach training is a recognized value allowing young coaches to become participants and get influence, and based on the results of this study, it can also be seen as the dictated way. The results show that the means of influence increase if one attends a course, but the support of a club member, who has a position of responsibility within the club, is also required. Without the support of important people, the room for action is limited. Another strategy that appears favorable for increasing one's capital and improving one's position is to be a member of the youth council or something similar. The environment is conducive to the young coaches being molded, the club's culture being inscribed in the body, and certain actions becoming self-evident.

The conclusion of the study is that if sport associations shall live up to the objectives that youths shall be able to influence and have real access to power (The Swedish Government 2004, p.25) "the rules of the game" need to change. Change is required of who is invited to a meeting and how, and who may express oneself and how. Even if the present recruiting process means the sport associations are able to keep youths that perhaps otherwise would have left, it also means the existing traditions are passed on and the orthodox routine is seldom challenged. 


\section{References}

Bourdieu, P. (1977). Outline of a theory of practice. Cambridge: Cambridge University Press.

Bourdieu, P. (1988). 'Program for a Sociology of Sport'. Sociology of Sport Journal, 5(2), 153-61.

Bourdieu, P. (1990). The Logic of Practice. Cambridge: Polity Press.

Bourdieu, P. (1992). Texter om de intellektuella [Texts on the intellectual]. Stockholm: Brutus Östlings bokförlag Symposium.

Bourdieu, P. (1993). The field of cultural production. Essays on art and literature. Cambridge: Polity Press.

Bourdieu, P. (1994). Centrale tekster inden for sociologi och kulturteori [Central texts for sociology and culture theory]. Köpenhamn: Akademisk förlag.

Bourdieu, P. (1995). Praktiskt förnuft. Bidrag till en handlingsteori Practical sense, Contributions to an action theory]. Göteborg: Daidalos.

Bourdieu, P. (1997). The Forms of Capital. In A. Halsey, H. Lauder, P. Brown \& A. Stuart Wells (eds) Education: Culture, Economy and Society (pp. 46-58). Oxford: Oxford University Press.

Bourdieu, P. (2000). Pascalian Meditations. USA: Stanford University Press.

Bourdieu, P. (2004). Science of Science and Reflexivity. Chicago: University of Chicago Press.

Bourdieu, P. \& Passeron, J-C. (2008). Reproduktionen [Reproduction]. Lund: Arkiv förlag.

Butcher, J., Lindner, K. J., \& Johns, D. P. (2002). Withdrawal from Competitive Youth Sport: A Retrospective Ten-year Study. Journal of Sport Behavior, 25(2), 145-163.

Denzin, N. K., \& Lincoln, Y. S. (1998). Collecting and interpreting qualitative materials. London: Sage Publ. 
Einarsson, T. (2008). Medlemskapet i den svenska idrottsrörelsen. En studie av medlemmar i fyra idrottsföreningar [Membership in Swedish sport associations. A study of members in four sport clubs]. Stockholm: The Swedish Sports Confederation.

Evans, S. D. (2007). Youth sense of community: Voice and power in Community Contexts. Journal of Community Psychology, 35(6), 693-709.

Franzen, M., \& Peterson, T. (2004). Varför lämnar ungdomar idrotten? [Why do young people leave sports?]. Report 3.

Fundberg, J. (2009). Villea är idrottens valda makthavare? - Om rekrytering till styrelser inom svensk idrott [Who are sports' elected leaders? - Recruitment to boards in Swedish sports]. Report 6.

Larsson, B. (2005). Arenor för alla: en studie om ungas kultur- och fritidsvanor [Arenas for everyone: A study on youth culture and leisure habits]. Stockholm, Youth Federation.

Larsson, L., \& Meckbach, J. (2010). Unga ledarprojekt inom Idrottslyftet [Young leaders project in the sports initiative]. Swedish Journal of Sport Research, 81-106.

MacPhail, A., Kirk, D., \& Eley, D. (2003). Listening to young people's voices: youth sports leaders' advice on facilitating participation in sport. European physical education review, 9(1), 57-73.

Marshall, C., \& Rossman, G. (2001). Designing Qualitative Research (5 ${ }^{\text {th }}$ ed.). London: Sage.

Meckbach, J., \& Larsson, L. (2011). Young Coaches and Supportive Environments. Sport Science Review, XX(5-6), 145-159.

Meckbach, J., \& Larsson, L. (2012). Education: one way to recruit and retain young coaches. The Journal of Youth Sports, 6(2), 25-31.

Munk, M. D. (1999). Livsbaner gennem felt - En analyse af eliteidratsoveres sociale mobilitet og rekonversioner af kapital i det sociala rum [Life's tracks through the field An analysis of elite athletes' social mobility and reconversion of capital in the social space]. Lund: Lunds universitet.

Munk, M. D., \& Lind, J. B. (2004). Idrattens kulturelle pol - En analyse af idretsfeltets autonomi belyst ved Pierre Bourdieus metoder [Sports' cultural pole - An analysis of 
sports field automony illustrated by Pierre Bourdieu's methods]. Köpenhamn: Københavns universitet.

Nelson, G., \& Prilleltensky, I. (2005). Community psychology: In pursuit of liberation and wellbeing. London: Palgrave Macmillan.

Nilsson, P. (1998). Fritid i skilda världar [Leisure time in different worlds]. Stockholm: Ungdomsstyrelsen.

Norberg, J. (2011). Uppföljning av statens stöd till idrotten [Monitoring of state aid to sports]. Stockholm: Centrum för idrottsforskning.

Pallin, C. (2004). Svensk idrotts uppbyggnad och organisation - ur ett associationsrättsligt perspektiv [Swedish sports structure and organization - from a association bylaw perspective]. Sveriges Riksidrottsförbund.

Redelius, K. (2002). Ledarna och barnidrotten. Idrottsledares syn på idrott, barn och fostran [The leaders and children's sports. Sports leaders' views on sports, children and upbringing]. [Dissertation]. Stockholm: HLS förlag.

Redelius, K. (2005) 'Idrottsungdomar - med rätt att påverka?’ [Sporting Youngsters: Entitled to Influence?] in K. Redelius \& H. Larsson (eds). Leve idrottspedagogiken! En vänbok tillägnad Lars-Magnus Engström [Long Live Sport Pedagogy! A Commemoration in Honour of Lars-Magnus Engström]. Stockholm, HLS förlag.

Redelius, K. (2007). Idrottsledarskap - ett lyft för ungdomar [Sports leadership - an initiative for youths]. RF:s och SISU:s skriftserie Idrottens ideella ledare.

Redelius, K., Auberger, G. \& Bürger Bäckström, C. (2004). Ung ledare sökes: En studie av Riksidrottsförbundets satsning på unga ledare [Young coaches wanted: A study of the Swedish Sports Confederation focus on young leaders]. Stockholm: SISU/RF.

The Swedish Government (2004). Makt att bestämma: rätt till välfärd [Power to decide: right to welfare]. Prop. 05, 2.

The Swedish Government (2005). Makt att forma sambället och sitt eget liv - nya mål i jämställdhetspolitiken [Power to shape society and one's own life - new goals in gender equality policies]. Prop. 06, 155. 
The Swedish Government (2011). Kultur, medier, trossamfund och fritid [Culture, media, religious organizations and leisure]. Prop. 11, 1.

The Swedish Sports Confederation (2005a). Idrotten vill. Idrottsrörelsens verksambetsidé och rikttinjer [Sports want. Sport associations mission and guidelines]. Stockholm: Riksidrottsförbundet.

The Swedish Sports Confederation (2011). Idrotten i siffror [Sports in digits]. Stockholm: Riksidrottsförbundet.

Sarrazin, P., Vallerand, R., Guillet, E., Pelletier, L. \& Cury, F. (2002). Motivation and Drop-out in female handballers: a 21-month prospective study. European Journal of Social Psychology, 32, 395-418.

The Swedish Government (1999). Förordning om statsbidrag till idrottsverksambet [Procedure on government grants for sports activities]. Svensk författningssamling, 1177.

Smyth, J. (2007). 'When students have power': student engagement, student voice, and the possibilities for school reform around 'dropping out' of school. International Journal Leadership in Education, 9(4), 285-298

The Swedish Government (2008). Föreningsfostran och tävlingsfostran. En utvärdering av statens stöd till Idrotten [Association education and competition education. An evaluation of national support for sports]. SOU, 59. Stockholm: Fritzes förlag.

Svender, J., Larsson, H. \& Redelius, K. (2012). Promoting girls' participation in sports: discursive constructions of girls in a sports initiative. Sport, Education and Society, 17(4), 463-478.

Trondman, M. (2005). Unga och föreningsidrotten: En studie om plats, betydelser och konsekvenser i ungas liv YYouths and club sports: A study of place, importance and consequences in young people's lives]. Stockholm: Ungdomsidrotten.

Trondman, M. (2011). Ett idrottspolitiskt dilemma - unga, föreningsidrotten och delaktigheten [A sports politics dilemma - young people, club sports and participation]. Report, 3. Stockholm: Centrum för idrottsforskning.

Ungdomsrådet (2011). Omungdomsrådet.Riksidrottsförbundets och SISU Idrottsutbildarnas ungdomsrad [The youth council. National sports confederation and SISU sports trainers youth council]. Stockholm: Riksidrottsförbundet. 
Lena LARSSON, PhD is currently senior lecturer at Linnaeus University in Kalmar, Sweden where she has been for the last 13 years. She is also Head of the Department of Sport Science. She earned her Ph.D. in Education at Stockholm University in 2009 with the thesis: Sport - and preferably a little more sport. P. E. students' encounter with the education. Her current research areas include teacher training and physical education from a pedagogical and gender perspectives but also young coaches in education. She publishes regularly in pedagogy and sociological journals both international and national and presents at the Australian Association for Research in Education, British Educational Research Association and AIESEP international Congress.

\section{Corresponding address:}

Lena Larsson

Department of Sport Sciences

Linneaus University,

S-391 82 Kalmar, Sweden

Phone: $+46(0) 470-708938$

Mobile: +46 (0)70-8746291

Email: lena.larsson@lnu.se

Jane MECKBACH, Ph D is currently a senior lecturer at The Swedish School of Sport and Health Sciences $(\mathrm{GIH})$ in Stockholm, Sweden, where she has been for the last 20 years. She is also Dean of the faculty Board at GIH. She earned her Ph D in Pedagogy at Stockholm University 2003 with the thesis: Movement in Motion - the subject of Gymnastics in the PETE programme at Royal Central Institute of Gymnastics/ Stockholm College of Physical Education and Sports during the years 1944 to 1992 . Her current research areas include teacher training and physical education from a pedagogical and gender perspectives but also young coachers in education. She publishes regularly in pedagogy and sociological journals both international and national; YouthFirst The Journal of Youth Sports, Sport in Society, Scandinavian Sport Studies Forum, Physical Education and Sport Pedagogy, Swedish Journal of Sport Research. She can be contacted at: jane.meckbach@gih.se 